\title{
The Relationship between Self-Concept, Self- Efficacy, and Military Skills and Abilities
}

\author{
Ole Boe \\ University of South-Eastern Norway \\ Drammen, Norway \\ Reidar Säfvenbom \\ Norwegian School of Sport Sciences \\ Oslo, Norway \\ Rino Bandlitz Johansen \\ Norwegian Defence University College \\ Oslo, Norway \\ Robert Buch \\ Oslo Met \\ Oslo, Norway
}

\begin{abstract}
This study investigated the relationship between academic self-concept, academic self-efficacy and the self-reported acquirement of certain specific military skills and abilities. Our sample consisted of 141 military cadets from the Norwegian Military Academy (Army), the Royal Norwegian Naval Academy, and the Royal Norwegian Air Force Academy. Supporting our hypotheses, it was found that perceived academic self-concept related positively to self-efficacy, after controlling for initial levels of self-efficacy, and that self-efficacy relates positively to self-reported Individual Coping Capacity (ICC), Cooperation in Difficult Situations (CDS), and Motivation to Achievement (MA), this after controlling for the initial levels of these Military Skills and Abilities (MSA). We discuss the implications of these findings.
\end{abstract}

Keywords: self-concept; self-efficacy; military skills and abilities.

\section{Introduction}

"The rigors in combat can be extreme. In our profession, the will to succeed and to strive towards results that exceed the expected, is the difference between success and failure" (Forsvarsstaben, 2007. p. 160, our translation). This quotation found in the Norwegian Armed Forces Joint Operational Doctrine reveals some reasons why officers and soldiers may need a well-developed self- 
efficacy as they conduct their professional practice. Both officers and soldiers from the Norwegian Armed Forces (NAF) have been taking part in a multitude of operations across the world in an operational environment that has become increasingly difficult (Boe, Kjørstad, \& Werner-Hagen, 2012; Forsvaret, 2018; Forsvarsdepartementet, 2009). After a conventional "cold war" scenario where the Norwegian soldiers only guarded its own borders, recent international conflicts are of a much higher complexity. The conflicts that the NAF have participated in the recent decades has changed its character from more regular combat operations through operations meant to stabilize and then to peace operations that are more complex in nature (Forsvarsstaben, 2014). New challenges will also arise as the operational environment becomes less transparent and at the same time more complicated (Boe, Bergh, \& Johansen, 2017).

It has been stated that a large element of friction will be found in the wars that we will witness in the future. As a consequence of this friction, this will be very demanding for the single officer or soldier (Watts, 2004). The modern operational military environment is a mix of different factors, such as changes, uncertainty, complexity, and ambiguity. Stiehm (2002) refers to these types of situations as VUCA situations. VUCA is an acronym that is commonly used to describe the volatility, uncertainty, complexity and ambiguity of different situations and conditions. As a consequence of these types of situations, military leaders are forced to constantly ponder upon their values, norms, and roles that should be a part of their profession (Snider \& Matthews, 2012; Sookermany, 2013).

Officers first has to be educated and trained to handle these operational environments (Boe, 2018). The document that governs the Norwegian Military Academy (Army), the Royal Norwegian Naval Academy, and the Royal Norwegian Air Force Academy and the education given at these military academies is the Norwegian Armed Forces Joint Operational Doctrine (FFOD) (Forsvarsstaben, 2014). FFOD states that stress in combat can be extreme, and that the will to succeed and to strive towards results that exceed what is expected may account for the difference between achieving success or failure (Forsvarsstaben, 2007). This statement highlights the importance for officers to believe in their ability to conduct their profession. The United States Army describe the need for leadership development in its Army Doctrine Publication ADP 6-22 (US Army, 2012). ADP 6-22 states that in decentralized operations, it is required from army leaders that they are able to adapt their thinking, their formations, and the employment of techniques in order to face the specific situation at hand. An adaptable and innovative mind and an ability to make adjustments based on continuous assessment are required in order to accomplish this (p. 0). In order to accomplish this, it is believed that one has to have a stable self-concept (Rosenberg, 1979) and a high degree of self-efficacy (Bandura, 1997).

Brown (2000) has shown that going through a military education in a military academy is psychologically, physically, and socially demanding. The purpose of 
these demands is to prepare the cadets to lead in extreme environments after graduating. Brown reviewed research on military cadets, and concluded that military academic life was a significant contributor to the psychological development of the cadets at the military academies. According to social cognitive theories (SCT) (Bandura, 1997) such subjective convictions as academic self-concept and self-efficacy about oneself will play a very important role in a person's further growth and development (Markus \& Nurius, 1986). An important factor thus becomes an individual's ability to create a high degree of self-efficacy (Eid, 2006) as to facilitate the acquirement of specific military skills and abilities (Johansen, Laberg, \& Martinussen, 2013; Solberg, 2007). This ability is required in order for the soldier or officer to function well and to be able to lead in different missions, in particular because individuals with a high degree of self-efficacy persist in failure and deal with difficulties in a more efficient way (Jex et al., 2001). Self-efficacy is thought to increase performance through different mechanisms. For instance, individuals that reveal high levels of selfefficacy tend to set more difficult goals for themselves. They also use more effort and they persist for a longer time when faced with challenges. When faced with challenges and adversity, such individuals also reveal more resilience (Klassen \& Usher, 2010).

Additional research that takes a closer look at academic self-efficacy and academic self-concept simultaneously is thus needed, as this type of studies seems to be quite rare (e.g., Bandalos et al., 1995; Choi, 2005; Lent, Brown, \& Gore, 1997; Pajares \& Miller, 1994). This research may then shed some light on the explanatory and mediating dimensions of both academic self-efficacy and academic self-concept. The present study investigating whether academic selfconcept is positively related to self-efficacy and if self-efficacy could explain how military skills and abilities are acquired is an attempt in line with the previously defined need for this type of research.

Previous research on military skills and abilities in a military context are limited. The need for more research by using for instance sport psychology has been requested lately (Flore \& Salas, 2008). Janelle and Hillmann (2003) state that by knowing the underlying mechanisms for performance in high level athletes, one may also gain insight in underlying factors that leads to to instruction and effective practice, and also to support networks. These factors may facilitate the processes of performance and learning in military contexts. Two underlying mechanisms that probably play a key role in this respect are self-concept and self-efficacy. Self-efficacy has been found to be a significant contributor as to whether soldiers succeeded in completing a very hard selection into the US Special Forces or not (Gruber, Kilcullen, \& Iso-Ahola, 2009). Similarly, a metaanalysis on math self-concept revealed that there existed strong relations between self-concept and achievement (Ma \& Kishor, 1997). However, the relationship between self-concept and self-efficacy has been shown to be somewhat unclear in the present research literature. For instance, while Bong and Skaalvik (2003) argued that academic self-efficacy should promote academic self-concept, Ferla. Valcke and Cai (2009) argued that students' academic selfconcept should promote students' sell-efficacy beliefs. 
Accordingly, in answering calls for longitudinal research on academic selfconcept and academic self-efficacy (e.g., Ferla, et al., 2009), our main purpose in the present study was to investigate the relationships between academic selfconcept, academic self-efficacy, and military skills and abilities over time. Specifically, we propose that academic self-concept relates positively to an increase in self-efficacy, and that self-efficacy then is related positively to an increase in three specific military skills and abilities. These specific military skills and abilities were individual coping capacity, cooperation in difficult situations, and motivation to achievement. A third purpose was to investigate further the relationship between self-concept and self-efficacy as this has been shown to be somewhat unclear in the present research literature. By doing so, we intend to make a contribution to the understanding of the psychological mechanisms that can be found underneath these three specific military skills and abilities. As research seems to be lacking within this field, our study may be an important contribution to the research field.

\section{Theoretical Background}

The next sections will discuss the concepts of self-concept and self-efficacy, as well as the relationships between the two concepts. We then deduct our first hypothesis from this theoretical background Then we shed some light on how self-efficacy is related to military skills and abilities. We then deduct our second hypothesis from this additional theoretical background.

\section{Self-Concept}

Rosenberg (1979) has defined self-concept as "...the totality of the individual's thoughts and feelings having reference to himself as an object" (p. 7). A similar definition of self-concept has been given by Shavelson, Hubner and Stanton (1976, p. 411): “...self-concept is a person's perception of himself"...Ones perceptions of himself are thought to influence the ways in which he acts, and his acts in turn influence the ways in which he perceives himself..." Shavelson et al. (1976) postulated that through one's experiences with one's environment, one's self-concept is formed. Morreale (2011) investigated the academic motivation and academic self-concept of military veterans, and found that being exposed to combat did not relate neither to academic motivation nor to academic self-concept. According to Marsh and O'Mara (2008), one's self-concept is further influenced by reinforcements that stems from one's environment and from other persons that are significant to you. Investigating Portuguese Navy trainees, Frade and Veiga (2016) found that trainees with more self-concept and living offbase reached a higher level of engagement compared to trainees that presented a lower level of self-concept. Furthermore, those trainees living onbase with a low self-concept revealed a higher level of engagement when they were compared to those trainees that were not living at the base. Different aspects of self-concept may be seen to form a self-schema (Hughes, Galbraith, \& White, 2011). This self-schema seems to include beliefs about one's, roles, abilities, experiences, and skills, but also beliefs about ones personal characteristics (Jerslid, 1965: Marsh \& Shavelson, 1985; West \& Fish, 1973). 
For the purposes of the present study, and following Ferla et al. (2009), we focus on academic self-concept. Academic self-concept dwells around individuals' perception of their competence within different academic domains (Harter, 1982). Academic self-concept is further connected to the perceptions and knowledge that individuals have about themselves in academic situations where achievement is expected (Byrne, 1984; Shavelson \& Bolus, 1982; Wigfield \& Karpathian, 1991). The concept of academic self-efficacy revolves around the assumption that the belief you have in your academic skills and in your abilities will predetermine your following motivation and feelings. This is accomplished through a mechanism that is self-regulating, and academic self-efficacy is simply the degree to which you believe that you will complete the education you are going through (Bandura, 1986; Pajares \& Miller, 1994; Schunk \& Zimmermann, 1997; Zimmermann. 2000). For instance, in a study on medical students conducted by $\mathrm{Yu}$, Chae, and Chang (2016), academic self-efficacy was found to be a partial mediator regarding the relationship between on one hand, sociallyprescribed perfectionism, and on the other hand, academic burnout.

\section{Self-Efficacy}

For military professionals, high standards are both expected and required. It should therefore not come as a surprise that a soldier or officer will need a strong self-efficacy to deal with VUCA situations they may encounter. Bandura (1986, 1997) postulated that self-efficacy emerges from four major sources, respectively enactive mastery experiences, vicarious experiences, verbal persuasion and physiological reactions. Bandura (1997, p. 3) later defined selfefficacy as "...[the] beliefs in one's capabilities to organize and execute the courses of action required to produce given attainments". This is about what one considers attainable with the skills one possesses and not about the abilities and skills one possesses (Bandura, 1986). There exists several meta-analyses that suggest that there is a positive relationship between self-efficacy and performance (Gully et al., 2002; Moritz et al., 2000; Multon, Brown \& Lent, 1991; Sadri \& Robertson, 1993; Stajkovic \& Luthans, 1998). It has also been shown that believing in one's own capacities, skills and abilities is important for Norwegian military officers within a variety of different tasks. Examples of such tasks are how professional soldiers learn aggression as well as aggression control (Boe \& Ingdahl, 2017), how to increase professional soldiers willingness to kill (Boe \& Johannessen, 2015), how to prepare officers for their first parachute jump (Boe \& Hagen, 2015), and how to enhance leadership communication skills of officer cadets (Boe \& Holth, 2017; Holth \& Boe, 2017). Self-efficacy has also been found to emerge as a partial moderating factor regarding the relationship between the conscientiousness domain in the Big Five and how one perform in a sample of Norwegian military cadets (Fosse et al., 2015).

Research has revealed that the strongest predictor of self-efficacy is enactive mastery experience (Boe \& Bergstøl, 2017; Britner \& Pajares, 2006; Lent, Lopez, \& Bieschke, 1991; Usher \& Pajares, 2008). Bandura also states that a very important factor for individuals when it comes to performing is self-efficacy (Bandura, 1997). Throughout all the educational processes, the perceived competence you think you have has been found to be an important contributor to success. 
Looking at research conducted on military personell, Adler, Thomas, and Castro (2005) found that the military competence that individuals reported they had correlated well with the demonstrated effort and expertise the same individuals showed. Investigating soldiers in an American Stryker brigade, Hammermeister et al. (2010) revealed that those that had revealed psychological skills that were well-developed showed a better performance on physical tests as compared to those that had revealed psychological skills that were less-developed. Similarly, the completion of a physically hard selection process was found to be significantly impacted by individual levels of self- efficacy (Gruber, Kilcullen, \& Iso-Ahola, 2009). Based upon these studies, it is therefore fair to say that psychological skills are important for both soldiers and officers. Contradicting this, Buch, Säfvenbom, and Boe (2015) found that for military cadets with a high level of intrinsic motivation, self-efficacy was of less importance as a mediator to increase their perception of their military competence. A preliminary conclusion one might draw from the above mentioned studies is that the role of self-efficacy in a military environment is still somewhat ambiguous and not well-defined clear-cut.

The Concepts of Self-Concept and Self-Efficacy and their Relationship

Some researchers have argued that self-concept and self-efficacy as constructs tend to be somewhat loosely defined at a conceptual level. As such, it then becomes difficult to construct a clear and operational definition of the constructs (e.g., Harter, 1982). Other researchers have argued that the constructs academicself-concept and academic self-efficacy clearly can be distinguished from each other, and that they have a different impact upon both motivation and subsequent behavior (e.g., Marsh, Walker \& Dubus, 1991). In an extension of prior research, we argue below that higher levels of academic self-concept should relate positively to higher levels of self-efficacy.

Social cognitive theory (Bandura, 1986) suggest that mastery experience is a core element of self-efficacy beliefs, and cadets with greater academic self-concept probably experience greater levels of mastery experience. This should promote the cadets' self-efficacy beliefs. To complicate the picture a bit more, it has been suggested that the construct of self-concept seems to include a component of the construct self-efficacy (Bong \& Clark, 1999; Pajares, 1996; Schunk, 1991). The two constructs, that is, self-concept and self-efficacy, can be seen to have several common elements. These are social comparison, experiences that you have from the past, and the reinforcements that comes from other people that are significant to you. Previous research has revealed that the two constructs can be linked to different outcomes that are deemed as desirable by students. Examples of such outcomes are academic achievement (Pintrich \& Schunk, 1996; Marsh \& Yeung, 1997), being persistent (Lent, Brown, \& Larkin, 1986; Skinner, Wellborn, \& Connell, 1990), and the internalization of task goals and achievement (Bong, 2001; Skaalvik \& Skaalvik, 2005). Also, the two constructs share many of the perceived results that are related to functioning both cognitively, affectively and behaviorally. Furthermore, linking the concept of self-concept to self-efficacy, Hughes, Galbraith, and White (2011) suggested that there exist an overlap between the different elements of the constructs of self-concept and self-efficacy. 
Other researchers claim that self-concept could include self-efficacy (Lent $e t$ al., 1997). Within the literature there is thus an ongoing discussion whether selfconcept and self-efficacy can be perceived as two distinctive and separated constructs or not. A common theme is that both self-concept and self-efficacy seem to reflect a greater perception of control that is personal (Pekrun, 2006). According to Pajares and Schunk (2001), both self-efficacy and self-concept beliefs have been especially dominant in motivation research.

However, Bong and Skaalvik (2003) suggest that self-efficacy leads to selfconcept but in another later study by Ferla et al. (2009) it was revealed that the participants' academic self-concept clearly correlated to a high degree with beliefs about academic self-efficacy. Ferla et al. (2009) showed that math selfconcept and math self-efficacy represented two conceptually and also empirically separated concepts. They also showed that students' academic selfconcept strongly influenced academic self-efficacy beliefs. In a similar vein, Bong et al. (2012) have found that self-beliefs, that is, self-concept and self-efficacy can be good for predicting the value a task has.

Further looking at the subjects of mathematics and modules of engineering education that were related to mathematics, Loo and Choy (2013) found that most important predictor for academic achievements within these subjects was mastery experience. Ferla et al. (2009) concluded that their findings underpinned both the conceptual and empirical differences found in the literature, specifically referring here to Bong and Skaalvik (2003).

Bong and Skaalvik (2003) asserted that academic self-concept is more oriented towards the past. They also asserted that one's perceived academic abilities was supported by judgments that were relatively stable. This relatively stable pastoriented judgment should increase future academic self-efficacy, which represents a more oriented towards the future assessment regarding the confidence an individual has when it comes to performance in academic tasks that are subject-specific (Ferla et al., 2009). Whereas self-efficacy beliefs develop over time and rest upon actual experiences (Caprara et al., 2011), cadets' academic self-concept may also represent a proxy for actual experiences that shapes their self-efficacy beliefs over time. Accordingly, cadets who have a favorable academic self-concept should exhibit a greater increase in future academic self-efficacy beliefs. In support of such arguments, Ferla et al. (2009) found that participating students' academic self-concept had a strong influence upon the beliefs the students had about their academic self-efficacy. Accordingly, we hypothesize:

Hypothesis 1: Academic self-concept relates positively to self-efficacy, after controlling for initial levels of self-efficacy.

\section{Self-efficacy and Military Skills and Abilities}

It has been stated that specific military skills are valid indicators of performance (Johansen, Laberg, \& Martinussen, 2013). In the present study, self-reports were used measuring perceived specific military skills and abilities and not actual specific military skills and abilities. One may ask whether self-reports are 
reliable indicators of performance. However, a comparison of self-reports and unit records among US soldiers revealed a satisfactory correlation, indicating that self-reports are valid reports of performance (Adler, Thomas \& Castro, 2005). The present study investigated three specific military skills and abilities, that is, individual coping capacity, cooperation in difficult situations, and motivation to achievement. These specific military skills were measured by the self-report instrument Military Skills and Ability (MSA) (Johansen, Laberg, \& Martinussen, 2013; Myrseth et al., 2018; Solberg, 2007). Specific military skills are comprised of certain skills and abilities that are necessary for soldiers when they are participating in operations and in combat. Military training aims at creating confidence in and achieving high standards performance in the military. This in order to make sure that soldiers has the ability to cope with combat contexts and complete their assigned missions (Driskell, Salas, \& Johnston, 2006; Krueger, 2008).

The MSA instrument is constructed of twenty statements and uses a Likert-type scale. The scale ranges from 1 (very bad) to 5 (very good). The self-report instrument is comprised of three subscales. The first subscale Individual Coping Capacity (ICC) (e.g., "Keeping a cool head in stressful situations" or "My ability to handle stress and difficult situations"). The second subscale Cooperation in Difficult Situations (CDS) (e.g., "Willingness to act on command in emergency situations" or "My ability to motivate and inspire others in difficult situations"). The third subscale Motivation to Achievement (MA) (e.g., "My motivation to participate in peacekeeping operations abroad"). Studies that have used the MSA instrument have yielded a Cronbach's alpha $>0.70$, indicating a high enough internal consistency (Laberg et al. 2002; Moldjord et al. 2015; Solberg 2007).

The research literature leaves no doubt that there exists a clear and also significant path between self-efficacy, motivation, and performance (Bandura, 1995). Empirically, self-efficacy has revealed itself to be negatively correlated to psychological distress and the perception of stress (Chan, 2002; Markstrom, 2001; Markstrom et al., 1997). Self-efficacy has further been found to be positively correlated to how one scores one's own health (Kristenson, Olsson \& Kucinskiene, 2005 (Bjorner et al., 1996; Idler \& Benyamini, 1997). It has been found that having high degree of self-efficacy increase the probability that one will set difficult personal goals for oneself (Bandura \& Locke, 2003). Furthermore, it has also been shown that setting challenging goals for oneself will lead to a better performance on the task one is engaged in (Brown. Jones, \& Leigh, 2005). For example, individuals that reveals a high degree of self-efficacy are more successful in their school work when they are compared to those with lower degree of self-efficacy (Multon, Brown, \& Lent, 1991). The same has been revealed in sports (Moritz et al., 2000) and at work (Stajkovic \& Luthans, 1998). Jex et. al. (2001) found that high self-efficacy individuals were more likely to believe that they would be able to comply with job demands when they are facing stressors. Research on Norwegian military cadets about to participate in a parachute course, revealed that the parachute course was a significant contributor to a higher level of self-efficacy before jumping out of the airplane 
(Boe, 2006; Boe \& Hagen, 2015). It then seems quite sensible that individuals displaying high self-efficacy will show a higher degree of individual coping capacity despite the presence of stressors. It has also shown that individuals that manage to maintain complexity under stress function better in groups. It is wellknown and documented fact that soldier's in a group will perform significantly better than they would have by themselves (Kellett, 1984). According to Watson (1978, p. 113) "The good squad is more than the sum of its parts". Moreover, it turns out that groups where individuals know each other well and have a welldeveloped sense of coherence perform significantly better in the war than groups that have just been created and where individuals to a lesser degree know each other (Dinter, 1985).

In addition, it has been found that business students that reveal a high degree of self-efficacy have a higher probability of becoming entrepreneurs (Zhao, Seibert, \& Hills, 2005). Also, those who believe that they have an ability to complete a task will show more interest in starting a task and then in implementing different strategies. This is also a solid predictor that these individuals will show a higher level of performance (Gerhardt, Rode, \& Peterson, 2007). An explanation could be that individuals are more achievement motivated simply because they already have acquired a high degree of self-efficacy. Stated a bit differently, these individuals just believe that achieving their goals are possible. Following this line of reasoning, we propose that self-efficacy increases military skills and abilities (see figure 1 below).

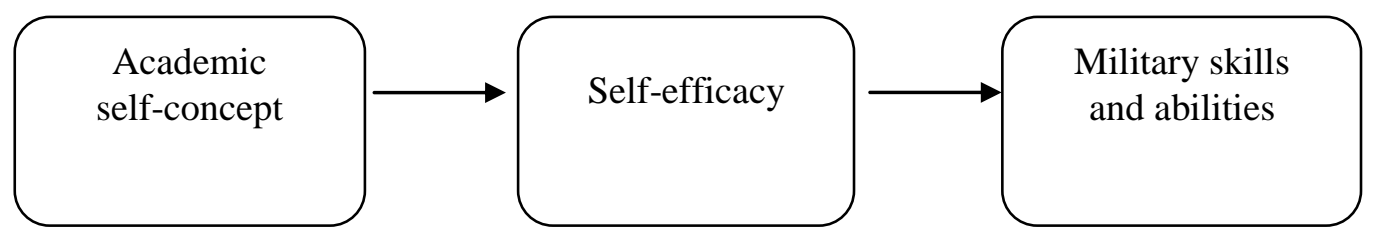

Figure 1. Conceptual model used in the study

Therefore, we hypothesize:

Hypothesis 2: Self-efficacy relates positively to a) individual coping capacity, b) cooperation in difficult situations, c) and motivation to achievement, after controlling for initial levels of these constructs.

\section{Method}

In this section we will reveal the method we used in the present study. An overview of our participants and the measures we used in the study will first be given, and thereafter we will reveal which control variables we used and how we analyzed our data.

\section{Participants and Procedure}

The data used in the present study was collected from cadets at the Norwegian Military Academy (Army), the Royal Norwegian Naval Academy, and the Royal Norwegian Air Force Academy at three consecutive points in time between 2007 and 2010 (referred to here as T1, T2, and T3). T1 data was collected when the cadets stated their first year at one of the academies. T2 data was collected when 
the participants finished their first year at one of the academies, and T3 data was collected when the participants finished their second year at one of the academies. The participants were given the information that that the survey was approved by the Norwegian Social Science Data Services (NSD) and strict confidentiality was assured. In accordance with the NSD rules regarding voluntary participation, our participants were subsequently also informed that it was completely voluntary to take part in the study. They were further informed that if they would like to withdraw from the study, they could do whenever they wanted. Participation on each time of measurement varied from 295 (T1) to 165 (T3). The total number of individuals who participated with data at all three measurement times consisted of 141 cadets. Our initial sample at T1 was $90.2 \%$ men and $9.8 \%$ women, and the mean age was 23.2 years $(\mathrm{SD}=2.72)$. Age, rank, and military experience in Norwegian military cadets are comparable to other countries in NATO (Johansen, Laberg, \& Martinussen, 2013).

\section{Measures}

Academic self-concept. Regarding the measurement of academic self-concept at T1, we decided to use the Self Perception Profile for Adolescents (SPPA) (Harter, 1988). Specifically, we used the dimension typically referred to as scholastic competence. Sample items include "I manage to complete my school work without any difficulties" and "I do well at school" (translated to Norwegian and back to English by the authors). The respondents were asked to indicate their responses on a 4-point scale ranging from 1 (totally disagree) to 4 (totally agree). We found the internal consistency to be high for this scale in our study, as Cronbach's alpha reached $\alpha=.80$.

Academic self-efficacy. As we wanted to measure self-efficacy at T1 and T2, we developed a seven-item scale that was specifically designed to capture the selfefficacy beliefs that participants would have regarding their ability to be successful in completing their military training and education (Buch, Säfvenbom, \& Boe, 2015). The Self-Efficacy Scale was developed because individuals have different self-efficacy beliefs in different activities and across domains, and as a consequence of this "there is no single all-purpose measure of self-efficacy with a single validity coefficient" (Bandura, 2012, p. 15).

Bandura (2012) has argued that general measures of self-efficacy that are not related to the context are less predictive and that they "usually bear weak relation both to domain-related self-efficacy beliefs and to behavior" (p. 16). On a general basis self-efficacy theorists thus not encourage using an all-purpose or more general instruments to measure self-efficacy (e.g., Pajares \& Urdan, 2006). For cadets to attain self-efficacy beliefs, they need to have acquired a knowledge regarding the environment and context that the military education at the academy takes place in. Answering this in the present study, we tailored the instrument so that it would fit to the academic domain that exist in a military academy. The items were thus designed so that they would measure the cadets perceived capability to manage process activities. These process activities, such as coping with difficult and hard times and getting through the education and still perform well, is of importance for academic performance. The stem used for each item was "With reasonable certainty, I can say that I..." The respondents 
were asked to indicate their responses on a 7-point scale ranging from 1 (totally disagree) to 7 (totally agree). Table 1 below shows the 7 questions that were used in the Self-Efficacy Scale (Buch, Säfvenbom, \& Boe, 2015).

Table 1: The Self-Efficacy Scale

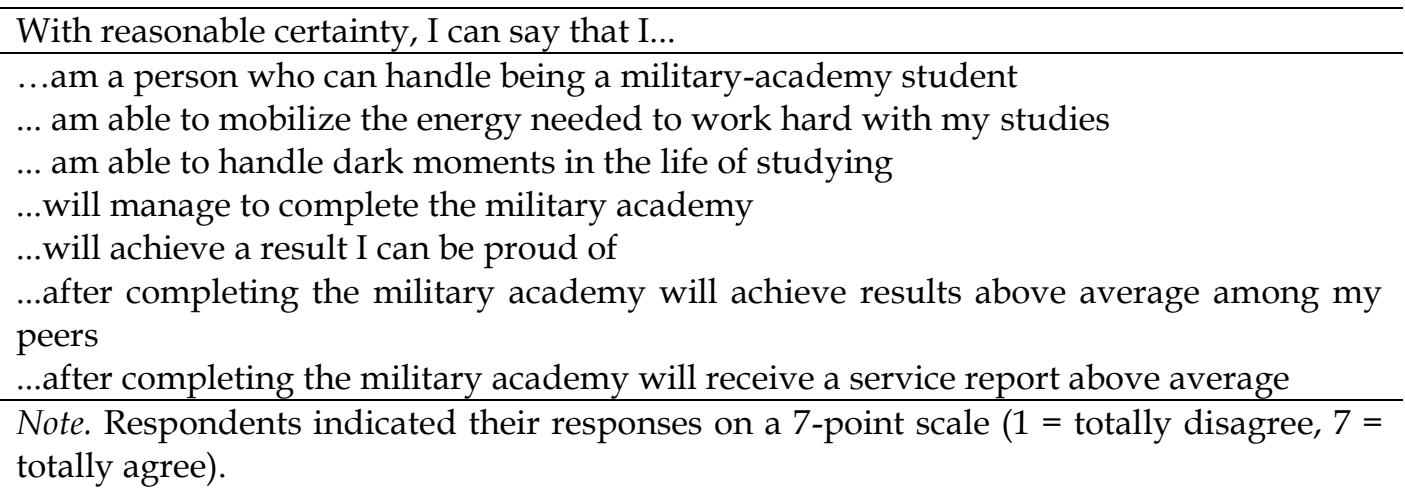

The scale was measured with an internal consistency of $a=.88$. (Nunnally, 1978, states that for exploratory measures the internal consistency should be above .70) providing an "indication of strong item covariance and suggests that the sampling domain has been captured adequately" (Hinkin, 1988, p. 113). Previous studies using The Self-Efficacy Scale have previously reported reliability estimates (Cronbach alpha's) ranging from 0.83 to 0.89 , thus revealing a high internal consistency (Buch, Säfvenbom, \& Boe, 2015; Fosse, Buch, Säfvenbom, \& Martinussen, 2015).

\section{Military skills and abilities}

For the measurement of initial military skills and abilities at T1 and at the follow-up survey at T3, we used the self-report instrument Military Skills and Abilities (MSA) developed by Solberg (2007) and previously used by Johansen, Laberg, and Martinussen (2013) and by Myrseth, Hystad, Säfvenbom, and Olsen (2018). The scale consists of twenty items that comprises three sub-dimensions: $\operatorname{ICC}(\alpha=.83), \operatorname{CDS}(\alpha=.70)$, and MA $(\alpha=.78)$. The overall $\alpha$ of the instrument is .78. The respondents recorded their responses on a five-point scale that ranged from 1 (very bad) to 5 (very good). Sample items include "My ability to make decisions in difficult situations is" (individual coping capacity), "My ability to give support to others in demanding situations is" (cooperation in difficult situations), and "My motivation to participate in peacekeeping operations abroad is" (motivation to achievement). Three items from the sub-dimension motivation to achievement was later removed from the analyses. Items 4 and 7 were removed due to low factor loading and item 1 was removed due to cross loading.

\section{Control variables.}

Self-perceptions with respect to athletic competence (AC), physical appearance (PA), and global self-worth (GSW), could influence self-efficacy beliefs and military skills and ability. We therefore controlled for AC $(\alpha=.80)$, PA $(\alpha=.79)$, and GSW ( $\alpha=.68)$ using the Self Perception Profile for Adolescents (Harter, 1988). Furthermore, we also controlled for any level of civilian education (CE) our participants had, as prior CE may influence the belief that the cadets had 
about their academic self-efficacy beliefs. Finally, we also controlled for the participants age and their gender $($ men $=1$; women $=2)$ in order to remove them as alternative explanations for our observed findings.

Data Analysis

We analyzed the data in several steps. First, in order to test whether the items measured reflected the latent constructs they were intended to and designed to measure (Hair et al., 2006), using the Mplus program we then performed a confirmatory factor analysis (CFA). To take into account the ordered categorical data (e.g., Flora \& Curran, 2004), we followed Muthén, du Toit, and Spisic (1997) guidelines and used the weighted least squares (WLSMV) estimator. The WLSMV estimator uses polychoric correlations among items. According to Jöreskog (1994), this is an effective procedure when one want to estimate models that consists of variables that are ordinal and dichotomous.

Given the fact that our data were nested (our respondents were nested within the Norwegian Military Academy (Army), the Royal Norwegian Naval Academy, and the Royal Norwegian Air Force Academy), the CFA was conducted using cluster robust standard errors at the academy level. Finally, in order to test our hypotheses, we ran separate hierarchical multiple regressions for each dependent variable.

\section{Results}

The results of a seven-factor CFA model, representing academic self-concept (ASC), self-efficacy (SE), MSA (individual coping capacity, cooperation in difficult situations, motivation to achievement), and the latent control variables (athletic competence (AC), physical appearance (PA), and global self-worth (GSW), provided a good fit with the data $\left(\chi^{2}[1009]=1602.66, p<0.01 ; \chi^{2} / \mathrm{df}=\right.$ 1.59; RMSEA $=0.045 ;$ CFI $=0.98$; TLI $=0.98)$. With the exception of the latent control variable GSW which fell slightly below the "magic threshold" of .70 ( $\alpha=$ .68), the scales also yielded high internal consistency, with reliability estimates (Cronbach alpha's) ranging from .70 to .88. Hurley et al. (1997) recommend using the CFA when testing "whether the newly written items conform to the hypothesized structure the scale architect had in mind" (p. 672). Means, standard deviations and bivariate correlations are reported below in Table 2. As can be seen, the zeroorder correlations were found to be in the predicted direction. Academic selfconcept at T1 was revealed to be positively related to self-efficacy at T2 $(r=.37, p$ $<.01)$, which in turn, was positively related to a) ICC at T3 $(r=.38, p<.01), \mathrm{b})$ CDS at T3 $(r=.26, p<.01)$, and c) MA at T3 $(r=.14$, n.s. $)$, although the latter relationship failed to reach statistical significance. 
Table 2: Means, standard deviations and bivariate correlations

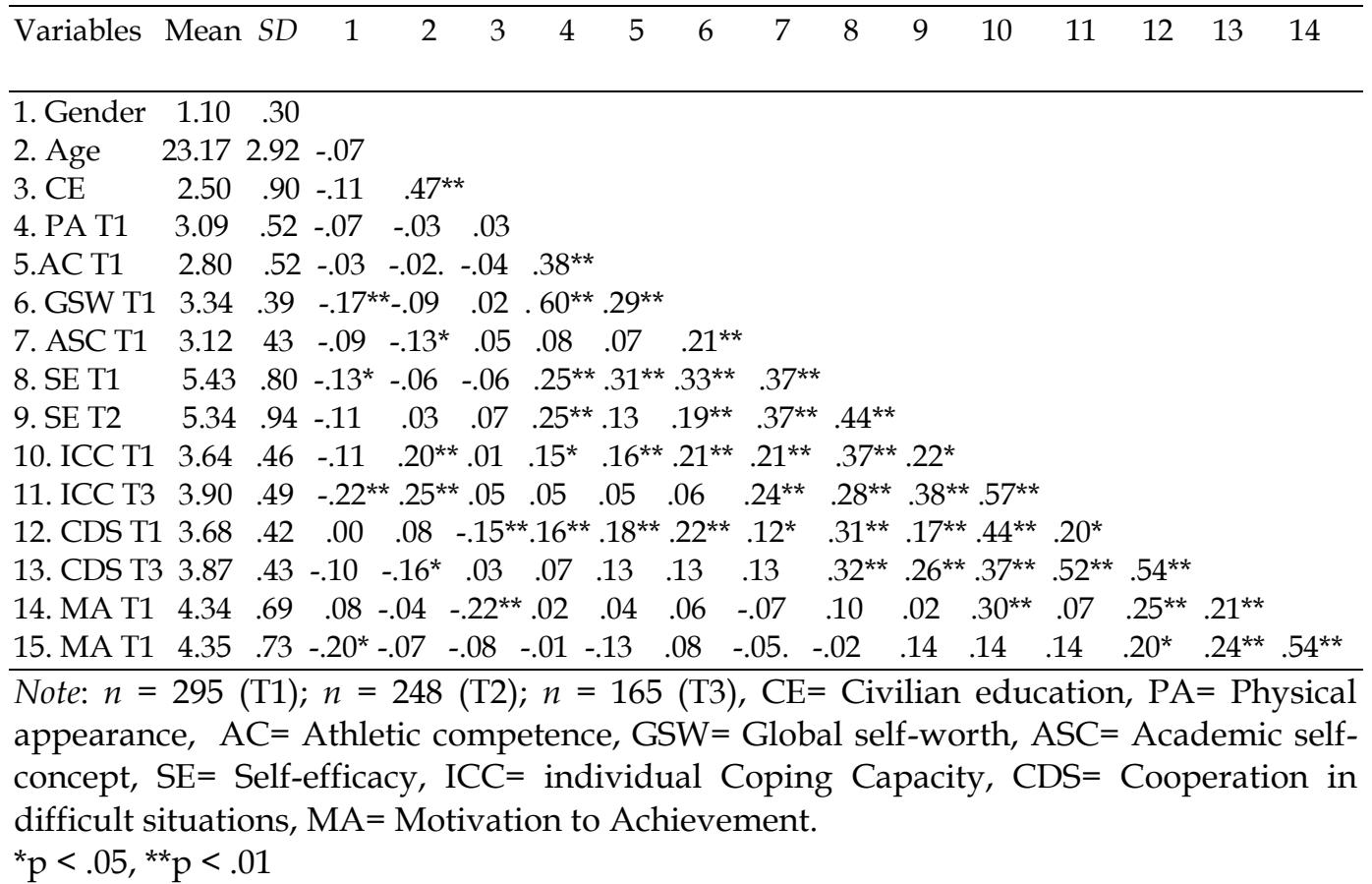

Our first hypothesis was that ASC relates positively to SE, after controlling for initial levels of SE. Our second hypothesis was that SE relates positively to MSA, after controlling for initial levels of MSA. The results of the hierarchical multiple regressions can be found in Table 3 and 4 below.

Table 3: Hierarchical regression analysis predicting SE (T2) from academic selfconcept (T1) while controlling for SE at Time 1

\begin{tabular}{lcc}
\hline & \multicolumn{2}{c}{ Self-efficacy T2 } \\
& Step 1 & Step 2 \\
\hline Control variables & -.04 & -.03 \\
Gendera & .01 & .06 \\
Age & .07 & .01 \\
Civilian education & $.16^{*}$ & $.16^{*}$ \\
Physical appearance T1 & -.03 & -.01 \\
Athletic competence T1 & -.02 & -.05 \\
Global self-worth T1 & & \\
& & \\
Initial level of self-efficacy & $.41^{* * *}$ & $.33^{* * *}$ \\
Self-efficacy T1 & & \\
Predictor & & $.26^{* * *}$ \\
Academic self-concept T1 & & $11.16^{* * *}$ \\
F & $9.52^{* * *}$ & .28 \\
$\mathrm{R}^{2}$ & .22 & $.06^{* * *}$ \\
$\Delta \mathrm{R}^{2}$ & &
\end{tabular}

Note: $n=295$ (T1); $n=248$ (T2); $n=165$ (T3). ${ }^{\text {amen }}=1$; women $=2$.

${ }^{*} \mathrm{p}<.05,{ }^{* *} \mathrm{p}<.01,{ }^{* * *} \mathrm{p}<.001$ 
As demonstrated by Table 3, there was a positive relationship between ASC at $\mathrm{T} 1$ and SE at T2 $(\beta=.26, p<.01)$, after controlling for the effect of initial level of SE at T1. Accordingly, we obtained support for Hypothesis 1.

Table 4: Hierarchical regression analysis predicting MSA (T3) from SE (T2) while controlling for MSA at Time 1 (T1)

\begin{tabular}{|c|c|c|c|c|c|c|}
\hline & & & $\overline{C D}$ & & & T3 \\
\hline & Step 1 & Step 2 & Step 1 & Step 2 & Step 1 & Step 2 \\
\hline Control ve & & & & & & \\
\hline Gendera & $.15^{*}$ & -.10 & -.03 & .00 & $-.24^{* *}$ & $-.21^{* *}$ \\
\hline Age & .07 & .10 & .11 & .13 & -.01 & .01 \\
\hline CE & -.03 & -.06 & .04 & .02 & -.03 & -.05 \\
\hline PA T1 & -.02 & -.08 & -.04 & -.08 & .07 & .04 \\
\hline AC T1 & .03 & .01 & .07 & .06 & -.16 & $-.18^{*}$ \\
\hline GSW T1 & -.08 & -.06 & -.01 & .00 & -.03 & -.02 \\
\hline ASC T1 & $.19^{*}$ & .06 & .14 & .06 & .03 & -.05 \\
\hline Initial $M$ & & & & & & \\
\hline ICC T1 & $.50^{* * *}$ & $.50^{* * *}$ & & & & \\
\hline CDS T1 & & & $.50^{* * *}$ & $.50^{* * *}$ & & \\
\hline MA T1 & & & & & $.51^{* * *}$ & $.51^{* * *}$ \\
\hline Predictor & & & & & & \\
\hline SE T2 & & $.31^{* * *}$ & & $.22^{* * *}$ & & $.19^{*}$ \\
\hline $\mathrm{F}$ & $9.26^{* * *}$ & $11.05^{* * *}$ & $7.07^{* * *}$ & $7.39^{* * * *}$ & $7.87^{* * *}$ & $7.41^{* * *}$ \\
\hline $\mathrm{R}^{2}$ & .36 & .43 & .30 & .34 & .32 & .35 \\
\hline$\Delta R^{2}$ & & $.07^{* * *}$ & & $.04^{* * *}$ & & $.03^{*}$ \\
\hline
\end{tabular}

Note: $n=295$ (T1); $n=248$ (T2); $n=165$ (T3). ${ }^{a}$ men $=1$; women $=2$.

ICC $=$ individual Coping Capacity, $\mathrm{CDS}=$ Cooperation in difficult situations, $\mathrm{MA}=$ Motivation to Achievement, $\mathrm{CE}=$ Civilian education, $\mathrm{PA}=$ Physical appearance, $\mathrm{AC}=$ Athletic competence, GSW $=$ Global self-worth, ASC $=$ Academic self-concept, SE $=$ Selfefficacy, MSA = Military Skills and Abilities.

${ }^{*} \mathrm{p}<.05,{ }^{* *} \mathrm{p}<.01,{ }^{* * *} \mathrm{p}<.001$.

Regarding the relationships between SE and MSA, Table 4 revealed that there existed a positive relationship between SE at T2 and ICC at T3 $(\beta=.31, p<.01)$, after controlling for the effect of initial level of ICC at T1. Support for Hypothesis $2 \mathrm{a}$ was thus yielded. Furthermore, in support of Hypothesis $2 \mathrm{~b}$, we found a positive relationship between SE at T2 and CDS at T3 $(\beta=.22, p<.01)$, after controlling for the effect of initial level of CDS at T1. Finally, we obtained support for Hypothesis 2c, as we found a positive relationship between SE at T2 and MA at T3 $(\beta=.19, p<.05)$, after controlling for the effect of initial level of MA at $\mathrm{T} 1$.

\section{Discussion}

Our main purpose in the present longitudinal study was to assess whether there existed a relationship between the constructs self-concept, self-efficacy and military skills and abilities. The results from our study leads to several theoretical implications. 
First, with respects to the hypothesized relationship between ASC and SE, we found that ASC relates positively to an increase in SE. This observation supports previous research suggesting that academic self-concept is an antecedent to selfefficacy (Ferla, et al. 2009). Furthermore, our study extends prior research relating academic self-concept and self-efficacy (e.g., Bong \& Skaalvik, 2003; Ferla, et al. 2009) by indicating that individuals with greater ASC also exhibit a greater increase in SE than those with a lower ASC. Hence, having a greater ASC when enrolling into a military academy seems to be beneficial when it comes to the cadets' being able to develop SE beliefs over time. Accordingly, our study contributes to the self-concept and self-efficacy literatures by clarifying the nature of the relationship between academic self-concept and self-efficacy.

Second, with respect to the relationships between SE and MSA, an important result from our longitudinal study is that SE relates positively to an increase in ICC, CDS, and MA. This finding extends prior research investigating antecedents to military skills and abilities among military cadets (Johansen, Laberg \& Martinussen, 2013: Myrseth et al., 2018) by indicating that cadets with higher levels of self-efficacy are able to increase their military skills and abilities to a greater degree during their education than cadets with lower levels of selfefficacy. Supporting this, other studies have revealed that high self-efficacy has been found to promote helpfulness, to promote an orientation and cooperation towards others, and to promote an interest in the health and wellbeing of others (Bandura et al., 1996; Bandura et al., 1999).

Third, our results yielded a positive relationship between SE and later ICC, CDS and MA. This fits well with Wrzesniewski et al. (2014) study of 10,000 West Point cadets over the period of 10 years. The results from this study revealed that the cadets internal motivation for military service was itself a predictor for "whether they would become commissioned officers, extend their officer service beyond the minimum required period, and be selected for early career promotions" (p. 10990).

Interestingly, although we did not hypothesize this, we observed a negative relationship between gender and MA, suggesting that women's motivation to engage in peacekeeping operations abroad tend to decrease during their military training and education. Previous research has shown that military personnel developed more negative attitudes towards peace-keeping missions over time (Laberg et al., 2005).

Although tentative, our observation could perhaps be explained by gender differences in that women seem to have a tendency to make less favourable social comparisons when judging their intellectual abilities (Goethals, Messick, \& Allison, 1991). Another possible explanation for this finding is that women to a higher degree than men attribute their academic success to external factors, for instance luck (Leppin et al., 1987). This is in line with other findings (Ferla et. al, 2009; Marsh \& Yeung, 1998; Pajares \& Miller, 1994) revealing that women have a lower degree of self-efficacy and that women also reveal a lower math selfconcept and math self-efficacy than males. 


\section{Limitations and Research Directions}

There are a few limitations that should be taken into account when we interpret our results. First, although we used a longitudinal design, our data were correlational and this hampers any possible assumptions about causality. Still, by investigating the variables at different points in time, such potential problems could be minimized (Podsakoff et al., 2003). In addition, we took into consideration several procedural countermeasures.

We made sure that the respondents were anonymous, and we also separated psychologically the scale items for both the predictor and the mediating variable (Podsakoff et al., 2003). We followed some of the procedural countermeasures that Podsakoff et al. (2003) suggests and in this way did our best to minimize the common method bias. As an example, when we emphasized confidentiality we expected a reduction in the potential common method variance (CMV). This emphasis was expected to reduce the probability that respondents would "edit their responses to be more socially desirable, lenient, acquiescent, and consistent with how they think the researcher wants them to respond" (Podsakoff et al. 2003, p. 888).

Second, our reliance on self-reported data when it comes to self-efficacy and MSA relationships may have affected the validity of our findings. In addition, according to Elstad (2010), if respondents are alone when filling out questionnaires, there is an increased risk that they will lose focus. On the other hand, although our study was based solely on self-report measures conducted at three points in time, we think that we avoided the tendency for CMV and inflated ratings (Podsakoff et al., 2003). Furthermore, we separated psychologically the independent and the dependent variables in time when we collected the data. We estimate that this helped to reduce any possible influence of CMV, as this has been shown to be a good approach to this problem (Podsakoff et al., 2003). There is also research that reveals that interactions that are statistically significant are not probable results of CMV (Harrison, McLaughlin \& Coalter, 1996; Siemsen, Roth \& Oliveira, 2010). Adler, Thomas, and Castro (2005) has found that there exist a sufficing similarity between soldiers self-reported data and their unit records when it comes to performance in different domains in a military context such as the one in the present study. Nonetheless, any research in the future should aim to collect data that come from different sources and variables. As an example of this, data could be collected from peers (Bang et al., 2015; Matthews et al., 2011; Zazanis, Zaccaro, \& Kilcullen, 2001).

Thirdly, there are some limitations to the use of a 5 point Likert-scale. A wellknown phenomenon is referred to as the social desirability bias (Garland, 1991). This means that the respondents tend to use the mid-point of the answering scale, as they do not want to give an answer that may be interpreted as a socially unacceptable one. The result of this is that the respondents tend to answer what they think is expected of them, instead of what they were thinking of. Silvera and Seger (2004) have also reported that specifically Norwegians have a tendency to avoid using the ends of the scales when rating their answers. 
Fourthly, the measurements used in the present study were not complicated. However, our participants may have felt a sense of overload because the present study was a part of a much larger study on Norwegian military cadets. A study on situational awareness conducted on a previous combat fatigue course has proved this tendency (Matthews et al., 2011). Another challenge in our study may be that the participants were not interested in the study and that this may have led to a less accurate scoring of themselves. In line with this, it has also been shown that a reduction in cognitive functioning may affect ones ability to focus (Vaitl et al., 2005).

Fifthly, our possibility to generalize our results may be limited by the sample we used to test our hypotheses. Our sample was based on military cadets at the Norwegian Military Academy (Army), the Royal Norwegian Naval Academy, and the Royal Norwegian Air Force Academy in Norway. These cadets have previously been through different selection procedures and may have different characteristics than a normal population.

Sixth, the use of quantitative method may give different answers as compared to if we had used qualitative methods. On the other hand, according to Ringdal (2001), the use of quantitative methods will increase the distance to the underlying data, and this can contribute to a more objective approach to the problem being investigated.

Seven, the measures of military skills in the present study were based on selfreport. This may be a weakness as self-reported skills may differ from "actual" military skills. However, a good enough similarity has been found in comparing self-reports from US soldiers with their unit records. This was found in domains where the soldiers were expected to perform and included that the soldiers were able to demonstrate effort and proficiency in soldiering (Adler, Thomas \& Castro, 2005).

Finally, as our sample consisted mainly of male cadets coming from the Norwegian Military Academy (Army), the Royal Norwegian Naval Academy, and the Royal Norwegian Air Force Academy in Norway, there is a risk that we cannot generalize our results beyond our population. If we want an extention of generalizability of our results we suggest that other countries and cultures are tested with the same instruments we used. We also suggest that similar studies with experimental designs should be conducted within other countries and in other sports, in the hope that our findings may lead to new directions in the research to come.

\section{Practical Implications}

Finally, we think that our study may yield a few implications that might be of importance in a practical sense. We think that military academies can use our findings in order to facilitate how to develop academic self-efficacy beliefs in their cadets. Following this line of thinking, van Dinther, Dochy, and Segers (2011) have suggested that higher education intervention programs can increase the cadets' beliefs about their self-efficacy. There is also research suggesting that 
the role of teachers may be crucial. This as self-efficacy seems to be receptive to changes in the instructions that are given from the teachers (Pajares \& Schunk, 2001; Robbins et al., 2004).

\section{Conclusion}

To summarize, our study offers empirical support that academic self-concept leads to self-efficacy and that self-efficacy leads to an increased individual coping capacity, cooperation in a difficult situation, and a motivation to achievement in a military academic context.

\section{Acknowledgements}

The present study and the conducted research has been supported by the Norwegian Defense University College and the South-Eastern University in Norway. The views that are expressed in this article are solely the authors and do not represent any official view held by the Norwegian Armed Forces. Our gratitude also extends to senior lecturer Merete Ruud at the Norwegian Military Academy for her valuable help with the English language in this article.

\section{References}

Adler, A. B., Thomas, J. L., \& Castro, C. A. (2005). Measuring Up: Comparing SelfReports With Unit Records for Assessing Soldier Performance. Military Psychology, 17, 3-24. https://doi.org/10.1207/s15327876mp1701_2

Bandalos, D. L., Yates, K., \& Thorndike-Christ, T. (1995). Effects of math self-concept, perceived self-efficacy, and attributions for failure and success on test anxiety. Journal of Educational Psychology, 87, 611-623. https://doi.org/10.1037/00220663.87.4.611

Bandura, A. (1986). Social foundations of thought and action: A social cognitive theory: Prentice-Hall, Inc.: Englewood Cliffs.

Bandura, A. (Ed). (1995). Self-Efficacy in Changing Societies. New York: Cambridge Univeristy Press. https://doi.org/10.1017/CBO9780511527692

Bandura, A. (1997). Self-efficacy: The exercise of control. New York: W. H. Freeman and Company.

Bandura, A. (2012). On the Functional Properties of Perceived Self-Efficacy Revisited. Journal of Management, 38(1), 9-44. https://doi.org/10.1177/0149206311410606

Bandura, A., \& Locke, E. A. (2003). Negative self-efficacy and goal effects revisited. Journal of Applied Psychology, 88, 87-99. https://doi.org/10.1037/0021-9010.88.1.87

Bandura, A., Barbaranelli, C., Caprara, G. V., \& Pastorelli, C. (1996). Multifaceted impact of self-efficacy beliefs on academic functioning. Child Development, 67, 1206-1222. https://doi.org/10.2307/1131888

Bandura, A., Pastorelli, C., Barbaranelli, C., \& Caprara, G. V. (1999). Self-efficacy pathways to childhood depression. Journal of Personality and Social Psychology, 76(2), 258-269. https://doi.org/10.1037/0022-3514.76.2.258

Bang, H., Boe, O., Nilsen, F. A., \& Eilertsen, D. E (2015). Evaluating character strengths in cadets during a military field exercise: Consistency between different evaluation sources. EDULEARN15 Proceedings, 7076-7082.

Bjorner, J., Kristensen, T. S., Orth-Gomer, K., Tibblin, G., Sullivan, M., \& Westerholm, P. (1996). Self-rated health: A useful concept in research, prevention, and clinical medicine. Stockholm: Swedish Council for Planning and Coordination of Research.

Boe, O. (2018). Officer Development at the Norwegian Military Academy. In S. Rawat (Ed.), Cadet Diary Psychology of Warrior Ethos and Cadet Leadership Development (pp. 167-184). Jaipur: Rawat Publications. 
Boe, O. (2006). Mestringskurs fallskjerm (Parachute course). Oslo: Norwegian Military Academy.

Boe, O., Bergh, J., \& Johansen, R. B. (2017). Leadership Challenges for Joint Force Commanders during the Transition from a High-intensity to a Low-intensity Conflict. Arts and Social Sciences Journal, 8(3), 281. https://doi.org/10.4172/2151$\underline{6200.1000281}$

Boe, O., \& Bergstøl, H-O. (2017). Theoretical and Practical Aspects of Self-Efficacy in Military Cadets. International Journal of Learning, Teaching and Educational Research, 16(7), 10-29.

Boe, O., \& Hagen, K. (2015). Using mindfulness to help reducing the perception of stress during an acute stressful situation. Procedia - Social and Behavioral Sciences, 197, 858868. https://doi.org/10.1016/j.sbspro.2015.07.262

Boe, O. \& Holth, T. (2017). Is Guidance as a Tool for Leadership Communication Effective for Military Leaders? Arts and Social Sciences Journal, 8(2), 263. https://doi.org/10.4172/2151-6200.1000263

Boe, O., \& Ingdahl, A. (2017). Educating monsters with brakes: Teaching soldiers aggression and aggression control. Kasmera Journal 45(3), 2-30.

Boe, O., \& Johannessen, A. H. (2015). The effects of the role of the group, the role of the leader, the emotional distance to the enemy, and the aggressive predisposition upon killing. Kasmera, 43(6), 125-144.

Boe, O., Kjørstad, O., \& Werner-Hagen, K. (2012). Løytnanten og krigen: Operativt lederskap $i$ strid [The lieutenant and the war: Operational leadership in war]. Bergen: Fagbokforlaget.

Bong, M. (2001). Between- and within-domain relations of academic motivation among middle and high school students: Self-efficacy, task-value, and achievement goals. Journal of Educational Psychology, 93, 23-34. https://doi.org/10.1037/00220663.93.1.23

Bong, M., Cho, C., Ahn, H. S., and Kim, H. J. (2012). Comparison of self-beliefs for predicting student motivation and achievement. Journal of Educational Research, 105, 336-352. https://doi.org/10.1080/00220671.2011.627401

Bong, M., \& Clark, R. E. (1999). Comparison between self-concept and self-efficacy in academic motivation research. Educational Psychology, 34, 139-154. https://doi.org/10.1207/s15326985ep3403_1

Bong, M., \& Skaalvik, E. M. (2003). Academic self-concept and self-efficacy: How Different Are They Really? Educational Psychology Review, 15, 1-40. https://doi.org/10.1023/A:1021302408382

Britner, S. L., \& Pajares, F. (2006). Sources of science self-efficacy beliefs of middle school students. Journal of Research in Science Teaching, 43(5), 485-499. https://doi.org/10.1002/tea.20131

Brown, R. (2000). Group Processes (2nd ed). Oxford: Blackwell Publishers.

Brown, S. P., Jones, E., \& Leigh, T. W. (2005). The Attenuating Effect of Role Overload on Relationships Linking Self-Efficacy and Goal Level to Work Performance. Journal of Applied Psychology, 90(5), 972-979. https://doi.org/10.1037/0021-9010.90.5.972

Buch. R., Säfvenbom, R., \& Boe, O. (2015). The Relationships Between Academic SelfEfficacy, Intrinsic Motivation, and Perceived Competence. Journal of Military Studies, 6(1). Retrieved from https://journal.fi/jms/article/view/49643. https://doi.org/10.1515/jms-2016-0195

Byrne, B. M. (1984). The general/academic self-concept nomological network: A review of construct validation research. Review of Educational Research, 54, 427-456. https://doi.org/10.3102/00346543054003427

Caprara, G V., Vecchione, M., Alessandri, G., Gerbino, M., \& Barbaranelli. C. (2011). The contribution of personality traits and self-efficacy beliefs to academic achievement: 
A longitudinal study. British Journal of Educational Psychology, 81, 78-96. https://doi.org/10.1348/2044-8279.002004

Chan, D. W. (2002). Stress, Self-Efficacy, Social Support, and Psychological Distress Among Prospective Chinese Teachers in Hong Kong. Educational Psychology, 22, 557-569. https://doi.org/10.1080/0144341022000023635

Choi, N. (2005). Self-efficacy and self-concept as predictors of college students' academic performance. Psychology in the Schools, 42(2), 197-205. https://doi.org/10.1002/pits.20048

Dinter, E. (1985). Hero or Coward: pressures facing the soldier in battle. London: Frank Cass and Company Limited.

Driskell, J. E., Salas, E., \& Johnston, J. H. (2006). Decision making and performance under stress. In: T. Britt, C. Castro, C., \& A. Adler (Eds.), Military Life: The Psychology of Serving in Peace and Combat (Vol. 1. Military Performance) (pp. 128-154.). Westport, CT: Praeger.

Eid, J. (2006). Emosjoner, stress og mestring [Emotions, stress and coping]. In J. Eid \& B. H. Johnsen (Eds.), Operativ psykologi [Operational psychology] (2nd ed.) (pp. 98-118). Bergen: Fagbokforlaget.

Elstad, J. I. (2010). Spørreskjemaundersøkelsens fallgruber [The pitfalls of questionnaires]. In D. Album, M. N. Hansen, \& K. Widerberg (Eds.), Metodene våre. Eksempler fra samfunnsvitenskapelig forskning [Our methods: Examples from social sciences research] (pp. 155- 169). Oslo: Universitetsforlaget.

Ferla, J., Valcke, M., \& Cai, Y. (2009). Academic self-efficacy and academic self-concept: Reconsidering structural relationship. Learning and Individual Differences, 19, 499505. https://doi.org/10.1016/j.lindif.2009.05.004

Flora, D. B., \& Curran, P. J. (2004). An empirical evaluation of alternative methods of estimation for confirmatory factor analysis with ordinal data. Psychological Methods, 9(4), 466-491. https://doi.org/10.1037/1082-989X.9.4.466

Flore, S. M., \& Salas, E. (2008). Cognition, Competition, and Coordination: The "Why" and the "How" of the Relevance of the Sport Sciences to Learning and Performance in the Military. Military Psychology, 20 (Suppl.), S1-S9. https://doi.org/10.1080/08995600701804764

Forsvaret. (2018). I tjeneste for Norge [In service for Norway). Retrieved from https://itjenestefornorge.no

Forsvarsdepartementet. (2009). "Fra vernepliktig til veteran» Om ivaretakelse av personell for, under og etter deltakelse i utenlandsoperasjoner". (Meld. St. 34 2008-2009) ["From conscript to veteran» About the attendance of personnel before, during and after participation in foreign operations". (Report 34 2008-2009)]. Oslo: Forsvarsdepartementet.

Forsvarsstaben (2014). Forsvarets fellesoperative doktrine [Norwegian Armed Forces Joint Operational Doctrine]. Oslo: Forsvarsstaben.

Forsvarsstaben (2007). Forsvarets fellesoperative doktrine [Norwegian Armed Forces Joint Operational Doctrine]. Oslo: Forsvarsstaben.

Fosse, T., Buch, R., Säfvenbom, R., \& Martinussen, M. (2015). The impact of personality and self-efficacy on academic and military performance: the mediating role of selfefficacy. Journal of Military Studies, 6(1). Retrieved from https://journal.fi/jms/article/view/52567. https://doi.org/10.1515/jms-2016$\underline{0197}$

Frade, A., \& Veiga, F. H. (2016). Military engagement, self-concept and on-base living. In F. H. Veiga (Ed.), Envolvimento dos alunos na escola: Perspetivas da psicologia e educação - Motivação para o desempenho académico [Students' engagement in school: Perspectives of psychology and education - Motivation for academic performance] (pp. 236-248). Lisboa: Universidade de Lisboa, Instituto de Educação. 
Garland, R. (1991). The Mid-Point on a Rating Scale: Is it Desirable? Marketing Bulletin, 2, 66-70.

Gerhardt, M. W., Rode, J. C., \& Peterson, S. (2007). Exploring mechanisms in the personality-performance relationship; Mediating roles of self-management and situational constraints. Personality and Individual Differents, 43, 1344-1355. https://doi.org/10.1016/j.paid.2007.04.001

Goethals, G. R., Messick, D. M., \& Allison, S. T. (1991). The uniqueness bias: Studies of constructive social comparison. In J. Suls \& T. A. Wills (Eds.), Social comparison: Contemporary theory and research (pp. 149-176). Hillsdale, NJ: Erlbaum.

Gruber, K. A., Kilcullen, R. N., \& Iso-Ahola, S. E. (2009). Effects of Psychosocial Resources on Elite Soldiers' Completion of a Demanding Military Selection Program. Military Psychology, 21, 427-444. https://doi.org/10.1080/08995600903206354

Gully, S. M., Incalcaterra, K. A., Joshi, A., \& Beaubien, J. M. (2002). A meta-analysis of team- efficacy, potency, and performance: Interdependence and level of analysis as moderators of observed relationships. Journal of Applied Psychology, 87(5), 819832. https://doi.org/10.1037/0021-9010.87.5.819

Hair, J. F., Black, W. C., Babin, B. J., Anderson, R. E., \& Tatham, R. L. (2006). Multivariate data analysis (6 $6^{\text {th }}$ ed.). Upper Saddle River, NJ: Prentice Hall.

Hammermeister, J., Pickering, M. A., McGraw, L., \& Ohlson, C. (2010). Relationship Between Psychological Skills Profiles and Soldier Physical Fitness Performance. Military Psychology, 22, 399-411. https:// doi.org/10.1080/08995605.2010.513238

Harrison, D. A, McLaughlin, M. E. \& Coalter, T. M. (1996). Context, Cognition, and Common Method Variance: Psychometric and Verbal Protocol Evidence. Organizational Behavior and Human Decision Processes, 68(3), 246-261. https://doi.org/10.1006/obhd.1996.0103

Harter, S. (1982). The Perceived Competence Scale for Children. Child Development, 53, 87-97. https://doi.org/10.2307/1129640

Harter, S. (1988). Manual for the Self-Perception Profile for Adolescents. Denver, CO: University of Denver.

Hinkin, T. R. (1998). A Brief Tutorial on the Development of Measures for Use in Survey Questionnaires", Organizational Research Methods, 1(1), 104-121. https://doi.org/10.1177/109442819800100106

Holth, T., \& Boe, O. (2017). Enhancing the Leadership Communication Skills of Norwegian Military Officers. Arts and Social Sciences Journal, 8(1), 250. https://doi.org/10.4172/2151-6200.1000250

Hughes, A., Galbraith, D., \& White, D. (2011). Perceived competence: A common core for self-efficacy and self-concept? Journal of Personality Assesment, 93(3), 278-289. https://doi.org/10.1080/00223891.2011.559390

Hurley, A. E., Scandura, T. A., Schriesheim, C. A., Brannick, M. T., Seers, A., Vandenberg, R. J., \& Williams, R. J. (1997). Exploratory and confirmatory factor analysis: Guidelines, issues, and alternatives. Journal of Organizational Behavior, 18(6), 667-683. https://doi.org/10.1002/(SICI)1099-1379(199711)18:6<667::AIDJOB874>3.0.CO;2-T

Idler, E. L., \& Benyamini, Y. (1997). Self-Rated Health and Mortality: A Review of Twenty-Seven Community Studies. Journal of Health and Social Behavior, 38, 21-37. https://doi.org/10.2307/2955359

Janelle, C. M., \& Hillman, C. H. (2003). Expert performance in sport: Current perspectives and critical issues. In J. L. Starkes \& K. A. Ericsson (Eds.), Expert performance in sports: Advances in research on sport expertise (pp. 49-83). Champaign, IL: Human Kinetics. 
Jerslid, A. T. (1965). Social and original origins of the self. In D. E. Hamachek (Ed.), The self in growth, teaching and learning (pp. 196-208). Englewood Cliffs, NJ: PrenticeHall.

Jex, S. M., Bliese, P. D., Buzzell, S., \& Primeau, J. (2001). The impact of self-efficacy on stressor-strain relations: Coping style as an exploratory mechanism. Journal of Applied Psychology, 86, 401-409. https://doi.org/10.1037/0021-9010.86.3.401

Johansen, R. B., Laberg, J. C., \& Martinussen, M. (2013). Military Identity as Predictor of Perceived Military Competence and Skills. Armed Forces $\mathcal{E}$ Society. https:// doi.org/10.1177/0095327X13478405

Jöreskog, K. G. (1994). On the estimation of polychoric correlations and their asymptotic $\begin{array}{llll}\text { covariance } \quad \text { matrix. } & \text { 38ychometrika, } 389 \text {. }\end{array}$ https://doi.org/10.1007/BF02296131

Kellett, A. (1984). Combat motivation: the behaviour of soldiers in battle. USA: Kluwer Publishing.

Klassen, R. M., \& Usher, E. L. (2010). Self-efficacy in educational settings: Recent research and emerging directions. In T. C. Urdan \& S. A. Karabenick (Eds.), The Decade Ahead: Theoretical Perspectives on Motivation and Achievement (Advances in Motivation and Achievement, (Part 16, pp. 1-33). Bingley: Emerald Group Publishing Limited.

Kristenson, M., Olsson, A. G., \& Kucinskiene, Z. (2005). Good Self- Rated Health is Related to Psychosocial Resources and a Strong Cortisol Response to Acute Stress: The LiVicordia Study of Middle- Aged Men. International Journal of Behavioral Medicine, 12, 153-60. https://doi.org/10.1207/s15327558ijbm1203_4

Krueger, G. P. (2008). Contemporary and future battlefields: Soldiers stress and performance. In P. A. Hancock \& , J. L. Szalma (Eds.), Performance Under Stress (Vol. 2 Operational) (pp. 19-44). Aldershot, UK: Ashgate.

Laberg, J. C., Ingjaldsson, J., Kobbeltvedt, T., \& Hoverak, J. (2005). Militær identitet under internasjonale operasjoner [Military identity during international operations]. Tidsskrift for Norsk Psykologforening, 42(4), 335-343.

Laberg, J. C., Johnsen, B. H., Eid, J., \& Brun, W. (2002). Mental preparedness during international operations. KFOR Survey. Report 1. Bergen: Royal Naval Military Academy/University of Bergen.

Lent, R. W., Brown, S. D., \& Gore, P. A., Jr. (1997). Discriminants and descriptive validity of academic self-concept, academic self-efficacy, and mathematics-specific selfefficacy. Journal of Counseling Psychology, 44, 307-315. https://doi.org/10.1037/0022-0167.44.3.307

Lent, R. W., Brown, S. D., \& Larkin, K. C. (1986). Self-efficacy in the prediction of academic performance and perceived career options. Journal of Counseling Psychology, 33, 265-269. https://doi.org/10.1037/0022-0167.33.3.265

Lent, R. W., Lopez, F. G., \& Bieschke, K. J. (1991). Mathematics self-efficacy: Sources and relation to science-based career choice. Journal of Counseling Psychology, 38(4), 424430. https://doi.org/10.1037/0022-0167.38.4.424

Leppin, A., Schwarzer, R., Belz, D., Jerusalem, M., \& Quast, H. H. (1987). Causal attribution patterns of high and low test-anxious students. In R. Schwarzer, H. van der Ploeg, \& C. Spielberger (Eds.), Advances in test anxiety research (Vol. 5, pp. 97106). H. Hillsdale, NJ: Erlbaum.

Loo, C. W., \& Choy, J. L. F. (2013). Sources of Self-Efficacy Influencing Academic Performance of Engineering Students. American Journal of Educational Research, 1(3), 86-92. https:// doi.org/10.12691/education-1-3-4

Ma, X., \& Kishor, N. (1997). Attitude Toward Self, Social Factors, and Achievement in Mathematics: A Meta-Analytic Review. Educational Psychology Review, 9, 89-120. https://doi.org/10.1023/A:1024785812050 
Markstrom, C. A. (2001). The psychometric properties of the Psychosocial Inventory of Ego Strengths for high school students. Unpublished manuscript. Morgantown: West Virginia University.

Markstrom, C. A., Sabino, V. M., Turner, B., \& Berman, R. C. (1997). The Psychosocial Inventory of Ego Strengths: Development and Validation of a New Eriksonian Measure. Journal of Youth and Adolescence, 26, 705-732. https://doi.org/10.1023/A:1022348709532

Markus, H., \& Nurius, P. (1986). Possible selves. American Psychologist, 41, 954-969. https:// doi.org/10.1037/0003-066X.41.9.954

Marsh, H. W., \& O'Mara, A. (2008). Reciprocal effects between academic self-concept, self-esteem, achievement, and attainment over seven adolescent years: Unidimensional and multidimensional perspectives of self-concept. Personality and Social Psychology Bulletin, 34(4), 542-552. https://doi.org/10.1177/0146167207312313

Marsh, H. W., \& Shavelson, R. (1985). Self-Concept: Its Multifaceted, Hierarchical Structure. Educational Psychologist, 20(3), 107-125. https://doi.org/10.1207/s15326985ep2003_1

Marsh, H. W., Walker, R., \& Debus, R. (1991). Subject-specific components of academic self-concept and self-efficacy. Contemporary Educational Psychology, 16, 331-345. https://doi.org/10.1016/0361-476X(91)90013-B

Marsh, H, W., \& Yeung, A. S. (1997). Causal effects of academic self-concept on academic achievement: Structural equation models of longitudinal data. Journal of Educational Psychology, 89, 41-54. https://doi.org/10.1037/0022-0663.89.1.41

Marsh, H. W., \& Yeung, A. S. (1998). Longitudinal structural equation models of academic self- concept and achievement: Gender differences in the development of math and English constructs. American Education Research Journal. 35(4), 705-738. https://doi.org/10.3102/00028312035004705

Matthews, M. D., Eid, J. Johnsen, B. H., \& Boe, O. (2011). A Comparison of Expert Ratings and Self-Assessments of Situation Awareness During a Combat Fatigue Course. Military Psychology, 23, 125-136. https://doi.org/10.1080/08995605.2011.550222

Moldjord, C., Laberg, J. C., \& Rundmo, T. (2015). Stressors, social support and military performance in a modern war scenario. Journal of Military Studies, 6(1), 1-18. https://doi.org/10.1515/jms-2016-0194

Moritz, S. E., Feltz, D. L., Fahrbach, K. R., \& Mack, D. E. (2000). The relation of SelfEfficacy Measures to Sport Performance: A Meta-Analytic review. Research Quarterly for Exercise and Sport, 71(3), 280-94. https://doi.org/10.1080/02701367.2000.10608908

Morreale, C. (2011). Academic motivation and academic self-concept: Military veteran students in higher education. (Doctoral dissertation). New York: University at Buffalo.

Multon, K. D., Brown, S. D., \& Lent, R. W. (1991). Relation of self-efficacy beliefs to academic outcomes: A meta-analytic investigation. Journal of Counseling Psychology, 38, 30-38. https://doi.org/10.1037/0022-0167.38.1.30

Muthén, B. O., du Toit, S. H. C., \& Spisic, D. (1997). Robust inference using weighted least squares and quadratic estimating equations in latent variable modeling with categorical and continuous outcomes. Unpublished technical report. Retrieved from https:// www.statmodel.com/download/Article_075.pdf.

Myrseth, H., Hystad, S. W., Säfvenbom, R., \& Olsen, O. K. (2018). Perception of specific military skills - the impact of perfectionism and self-efficacy. Journal of Military Studies, X(X), 1-15. https://doi.org/10.2478/jms-2018-0002

Nunnally, J. C. (1978). Psychometric theory (2nd ed.). McGraw-Hill, New York.

Pajares, F. (1996). Self- efficacy beliefs in academic settings. Review of Educational Research, 66(4), 543 -578. https:/ / doi.org/10.3102/00346543066004543 
Pajares, F., \& Miller, M. D. (1994). Role of self-efficacy and self-concept beliefs in mathematical problem solving: A path analysis. Journal of Educational Psychology, 86, 193-203. https://doi.org/10.1037/0022-0663.86.2.193

Pajares, F., \& Schunk, D. H. (2001). Self-beliefs and school success: self-efficacy, self-concept, and school achievement. In R. Riding \& S. Rayner (Eds.), Perception (pp. 239-266). London: Ablex Publishing.

Pajares, F., \& Urdan, T. (Eds). (2006). Self-Efficacy Beliefs of Adolescents. Greenwich, CT: Information Age Publishing.

Pekrun, R. (2006). The Control-Value Theory of Achievement Emotions: Assumptions, Corollaries, and Implications for Educational Research and Practice. Educational Psychology Review, 18, 315-341. https://doi.org/10.1007/s10648-006$\underline{9029-9}$

Pintrich, P. R., \& Schunk D. H. (1996). Motivation in education: Theory, research, and applications. Englewood Cliffs, NJ: Merrill/Prentice Hall.

Podsakoff, P. M., MacKenzie, S. B., Lee, J.-Y., \& Podsakoff, N. P. (2003). Common method biases in behavioral research: A critical review of the literature and recommended remedies. Journal of Applied Psychology, 88(5), 879-903. https:// doi.org/10.1037/0021-9010.88.5.879

Ringdal, K. (2001). Enhet og mangfold [Unity and diversity]. Bergen: Fagbokforlaget.

Robbins, S. B., Lauver, K., Le, H., Davis, D., Langley, R., \& Carlstrom, A. (2004). Do Psychosocial and Study Skill Factors Predict College Outcomes? A MetaAnalysis. Psychological Bulletin, 130(2), 261-288. https://doi.org/10.1037/0033$\underline{2909.130 .2 .261}$

Rosenberg, M. (1979). Conceiving the self. New York: Basic Books.

Sadri, G., \& Robertson, I. T. (1993). Self-efficacy and Work-related Behaviour: A Review and Meta-analysis. Applied Psychology, 42(2), 139-152. https://doi.org/10.1111/j.1464-0597.1993.tb00728.x

Schunk, D. H. (1991). Self-Efficacy and Academic Motivation. Educational Psychologist, 26, 207-231. https://doi.org/10.1080/00461520.1991.9653133

Schunk, D. H., \& Zimmermann, B. J. (1997). Social origins of self-regulatory competence. Educational Psychologist, 32, 195-208. https://doi.org/10.1207/s15326985ep3204_1

Siemsen, E., Roth, A., \& Oliveira, P. (2010). Common Method Bias in Regression Models With Linear, Quadratic, and Interaction Effects. Organizational Research Methods, 13(3), 456-476. https://doi.org/10.1177/1094428109351241

Shavelson, R. J., \& Bolus, R. (1982). Self-concept: The interplay of theory and methods. Journal of Educational Psychology, 74, 3-17. https://doi.org/10.1037/0022$\underline{0663.74 .1 .3}$

Shavelson, R. J., Hubner, J. J., \& Stanton, G. C. (1976). Self-concept: Validation of construct interpretations. Review of Educational Research, 46, 407-441. https://doi.org/10.3102/00346543046003407

Silvera, D. H., \& Seger, C. R. (2004). Feeling good about ourselves: Unrealistic SelfEvaluations and Their Relation to Self-Esteem in the United States and Norway. Journal of Cross-Cultural Psychology, 35(5), 571-585. https://doi.org/10.1177/0022022104268389

Skaalvik, S., \& Skaalvik, E. M. (2005). Self-Concept, Motivational Orientation, and HelpSeeking Behavior in Mathematics: A Study of Adults Returning to High School. Social Psychology of Education, 8, 285-302. https://doi.org/10.1007/s11218-005-3276-3

Skinner. E. A., Wellborn, J., \& Connell, J. (1990). What it takes to do well in school and whether I've got it: a process model of perceived control and children's engagement and achievement in school. Journal of Educational Psychology, 82, 2232. https:// doi.org/10.1037/0022-0663.82.1.22 
Snider, D., \& Matthews, L. J. (2012). The future of the army profession (2nd ed.). McGrawHill, Boston, USA.

Solberg, O. A. (2007). FN-obeservatøren: Stressorer og reaksjoner hos norske FN-observatører $i$ det tidligere Jugoslavia" [The UN-Observer: Stressors and Reactions in Norwegian UNobservers in the former Yugoslavia"]. (Master thesis) Trondheim: NTNU.

Sookermany, A. M. (2013). On Developing (Post)modern Soldiers. An Inquiry into the Ontological and Epistemological Foundation of Skill-Acquisition in an Age of Military Transformation. Oslo: Universitetet i Oslo.

Stajkovic, A. D., \& Luthans, F. (1998). Self-efficacy and work-related performance: A meta-analysis. Psychological Bulletin, 124(2), 240-261. https://doi.org/10.1037/0033-2909.124.2.240

Stiehm, J. H. (2002). The U.S. Army War College: Military Education in a Democracy. Philadelphia: Temple University Press.

US Army. (2012). ADP 6-22 Army leadership. Washington, DC: Headquarters, Department of the Army.

Usher, E. L., \& Pajares, F. (2008). Sources of self-efficacy in school: Critical review of the literature and future directions. Review of Educational Research, 78(4), 751-796. https://doi.org/10.3102/0034654308321456

van Dinther, M., Dochy, F., \& Segers, M. (2011). Factors Affecting Students' Self-Efficacy in Higher Education. Educational Research Review, 6(2), 95108. https://doi.org/10.1016/i.edurev.2010.10.003

Vaitl, D., Birbaumer, N., Gruzelier, J., Jamieson, G. A., Kotchoubey, B., Kubler, A., Lehmann, D., Milner, W. H., Ott, U., Putz, P., Sammer, G., Strauch, I., Strehl, U., Wackermann, J., \& Weiss, T. (2005). Psychobiology of Altered States of Consciousness. Psychological Bulletin, 131(1), 98-127. https://doi.org/10.1037/0033-2909.131.1.98

Watson, P. (1978). War on the mind. London: Hutchinson \& Co.

Watts, B. D. (2004). Clausewitzian friction and future war. Washington D.C.: Institute for National Strategic Studies, National Defense University. https://doi.org/10.21236/ADA427577

West, C. K., \& Fish, J. A. (1973). Relationships between self-concept and school achievement: A survey of empirical investigations (Final Report for the National Institute of Education). Urbana, IL: National Institute of Education.

Wigfield, A., \& Karpathian, M. (1991). Who Am I and What Can I Do? Children's SelfConcepts and Motivation in Achievement Situations. Educational Psychologist, 26, 233-261. https:// doi.org/10.1080/00461520.1991.9653134

Wrzesniewski, A., Schwartz, B., Cong, X., Kane, M., Omar, A., \& Kolditz, T. (2014). Multiple types of motives don't multiply the motivation of West Point cadets. Proceedings of the National Academy of Sciences, 111(30), 10990-10995. https://doi.org/10.1073/pnas.1405298111

Yu, J. H., Chae, S. J., \& Chang, K. H. (2016). The relationship among self-efficacy, perfectionism and academic burnout in medical school students. Korean Journal of Medical Education, 28(1), 49-55. https://doi.org/10.3946/kjme.2016.9

Zazanis, M. M., Zaccaro, S. J., \& Kilcullen, R. N. (2001). Identifying Motivation and Interpersonal Performance Using Peer Evaluations. Military Psychology, 13(2), 7388. https://doi.org/10.1207/S15327876MP1302_01

Zhao, H., Seibert, S. E., \& Hills, G. E. (2005). The Mediating Role of Self-Efficacy in the Development of Entrepreneurial Intentions. Journal of Applied Psychology, 90(6), 1265-1272. https://doi.org/10.1037/0021-9010.90.6.1265

Zimmermann, B. J. (2000). Attaining Self-Regulation: A Social Cognitive Perspective. In: M. Boekaerts, P. R. Pintrich, \& M. Zeidner (Eds.), Handbook of Self-Regulation (pp. 13-39). New York: JAI Press. http:// doi.org/10.1016/B978-012109890-2/50031-7 